História, (16), fev. 1998.

MARQUESE, Rafael B. A dinâmica da escravidão no Brasil: resistência, tráfico negreiro e alforrias, séculos XVII a XIX. São Paulo: Novos Estudos, CEBRAP, 74, p. 107-123, Março de 2006.

MOREL, Marco. O periodo das regências (1831-1840). Rio de Janeiro: Jorge Zahar, 2003.

MOTTA, José F; LOPES, Luciana S. O pecúlio dos escravos: concessão ou conquista? Economia \& História: crônicas de histórica econômica, p. 22-28, Maio de 2015.

PIRES, Maria F. N. Cartas de alforria: "para não ter o desgosto de ficar em cativeiro". Revista Brasileira de História. São Paulo, v. 26, nº 52, p. 141-174 - 2006

REIS, João José; SILVA, Eduardo. Negociação e conflito: a resistência negra no Brasil escravista. São Paulo: Companhia das Letras, 1989.

RIO GRANDE DO SUL. Secretaria da Administração e dos Recursos Humanos. Departamento de Arquivo Público. Documentos da escravidão: Catálogo seletivo de cartas de liberdade acervo dos tabelionatos do interior do Rio Grande do Sul / - Porto Alegre: CORAG, 2006.

SLENES, Robert W. Senhores e subalternos no Oeste Paulista. In: ALENCASTRO, Luiz Felipe de (org.). História da vida privada no Brasil: Império. São Paulo: Companhia das Letras, 1997. $233-290$.

Recebido em 10/04/16 - Aprovado em 04/07/16 


\title{
Historiografia sobre o campo de estudos especializado na saúde dos escravos negros.
}

\begin{abstract}
Alisson Eugênio ${ }^{1}$
Resumo: este artigo apresenta e discute a Historiografia sobre o campo de estudos especializado na saúde dos escravos negros, com ênfase na produção norte-americana e, principalmente, a brasileira, para mostrar ao público interessado em tal campo de estudos o que foi produzido e as possibilidades de novas produções.
\end{abstract}

Palavras-chave: historiografia, saúde e escravos negros.

Abstract: This article presents and discusses the Historiography on the area of specialized studies on the health of black slaves, with emphasis on North American production and, especially, Brazil, to show the public interested in this area of study which was produced and the possibilities for new productions.

Keywords: historiography, health and black slaves .

Há muito tempo os historiadores estudam a história da saúde da população escrava. Nos EUA desde pelo menos o estudo de Ulrich Phillips e no Brasil desde pelo menos o estudo de Octávio Freitas. ${ }^{2}$ Entre os norte-americanos o interesse por esse assunto cresceu consideravelmente ao longo do século XX, como indica sua copiosa produção historiográfica. Entre nós, somente na última década verifica-se aumento expressivo de trabalhos sobre o mesmo assunto. Ambos países formam, junto com o Caribe, as maiores áreas concentradoras de negros submetidos ao cativeiro nas Américas. Por essa razão, muito útil será como referência um levantamento de algumas das diversas pesquisas, que contemplam direta ou indiretamente a história das condições de saúde dos seus cativos.

Uma das primeiras publicações relevantes a esse respeito foi American negro slavery, impressa originalmente em 1918, de Ulrich Phillips. Embora seu estudo não

1 Professor Adjunto da Universidade Federal de Alfenas. E-mail: alissoneugenio@yahoo.com.br .

2 PHILLIPS (usarei a versão reimpressa de1966). FREITAS (1935). 
foque exclusivamente a saúde da população escrava, ele apresenta várias passagens relevantes sobre essa temática, com considerações instigantes que posteriormente foram examinadas com maior profundidade por outros estudiosos. Entre elas pode-se destacar a de que não havia normalmente por parte dos proprietários, mesmo os dos grandes empreendimentos agrícolas, uma completa negligência em relação às condições de vida dos escravos (uma vez que os investimentos senhoriais para adquiri-los e adaptá-los ao cativeiro nunca foram desprezíveis), principalmente após os debates que culminaram na supressão oficial do comércio internacional de africanos para os EUA, quando a reposição da mão de obra servil passou a depender da reprodução natural. ${ }^{3}$

Essa consideração é uma das mais importantes do ponto de vista historiográfico, porque contribuiu para incentivar trabalhos destinados a verificar até que ponto os senhores investiam na saúde dos indivíduos submetidos à escravidão, ou quais os limites para tal investimento e desde quando a preocupação com a preservação de tais indivíduos começou a ocorrer. Foi o que parte dos estudos subseqüentes procurou responder. Para isso, uma das estratégias metodológicas utilizadas foi a elaboração de um inventário das doenças que mais afetavam e mais matavam a população escrava, além da abordagem sobre atitudes senhoriais registradas em diários de fazendas (records) e memórias (inclusive de ex-escravos): contratação de médicos e enfermeiras, internação em hospitais, construção de enfermarias, utilização de manuais de medicina prática, melhoramentos em senzalas, aumento e variação da alimentação e vestuário, cada vez mais recorrentes a partir da segunda década do século XIX (após a extinção do tráfico transatlântico de africanos para os EUA). O estudo de tudo isso em conjunto, em regiões e épocas diferentes, permitiu a expansão dos horizontes de compreensão acerca da experiência histórica das condições de saúde nos cativeiros norte-americanos.

Para isso muitos autores empenharam-se desde a seminal obra de Phillips (1918) até a publicação de Medicine and slavery (1978), uma das mais completas e importantes pesquisas sobre esse assunto, elaborada pelo historiador Savitt Todd. Entre eles destacase William Dosite Postel, autor de diversos estudos sobre as condições de saúde da população cativa, como The health of slaves on southern plantations (1951) considerado como um dos melhores até então. ${ }^{4}$ Esse pesquisador elaborou um inventário das doenças

3 PHILLIPS (1966) p. 263-265.

4 Um dos autores que consideram o citado estudo de Postel como o melhor até então escrito é KAUFMAN (1979) p. 381. 
mais comuns e mais fatais dos cativos, concluindo que cólera, disenteria e pneumonia estavam entre elas, devido ao descuido com regras básicas de higiene (pouco difundidas na época), no caso das duas primeiras, e de carência de vitamina $\mathrm{C}$ e da exposição ao rigoroso frio do inverno, no caso da última. Tal descuido foi regra geral na maioria das fazendas das colônias do Sul, mas começou a desaparecer ao longo da primeira metade do século XIX e praticamente tornou-se incomum às vésperas da Guerra de Secessão $(1860)^{5}$

O mesmo destaque também deve ser atribuído a outros estudiosos que não se especializaram no tema em pauta, mas deram contribuições bastante relevantes para o seu aprofundamento. Um deles é Eugene Genovese, que no início dos anos 1960 elaborou um trabalho, ${ }^{6}$ no qual ensaiou a hipótese, aprimorada mais de uma década depois em várias de suas obras, como na clássica Roll Jordam Roll (1976), de que nas propriedades com menor absenteísmo e maior paternalismo (quer dizer: em propriedades em que os senhores se faziam mais presentes e viam seus escravos como extensão de suas famílias) houve um gerenciamento mais eficaz da escravaria, diminuindo as tensões sociais e favorecendo a redução das taxas de mortalidades.

Outro deles é Philip Curtin; autor de um dos primeiros estudos mais avançados sobre a relação entre doenças e tráfico transatlântico de escravos. ${ }^{7}$ Publicado no ano de 1968, seu Epidemiology and slave trade revela as doenças mais mortíferas durante o tráfico (escorbuto, diarréia, disenteria e varíola estão entre elas) e o seu impacto mórbido sobre a população transportada e seus possíveis efeitos nos escravos já adaptados. Por exemplo, muitas vezes algum escravo chegava aparentemente saudável nas fazendas, mas portava doença, geralmente contagiosa, que provocava considerável estrago demográfico. Esse estudo, cujas ideias centrais foram reiteradas no livro seguinte do mesmo autor, The Atlantic slave trade, ${ }^{8}$ acabou estimulando um debate, sobre as taxas de mortalidade durante a travessia até então consideradas altíssimas, que impulsionou diversas pesquisas, como as de Herbert Klein, autor de, por exemplo, The middle passage publicada em 1978, na qual procurou, entre outras tarefas, estabelecer uma taxa comparativa de eficiência do transporte de africanos pelos negreiros,

5 POSTEL (1951). Em 1954 esse autor reiterou suas conclusões em um artigo intitulado Survey on the chronic illnesses and physical impairments among slave population in the Ante-bellun South. Bulletin of Medical Library Association. V. 42, n 2, 1954, p. 158.

6 GENOVESE (1960).

7 CURTIN (1968).

8 CURTIN (1969). 
calculando taxas médias de mortalidade estimada por navio.

A historiografia norte-americana sobre a relação entre saúde e escravidão foi impulsionada pelo livro de Robert Fogel e Stanley Engerman, Time on the cross, publicado em 1974, na esteira das proposições metodológicas da New economic history em que por meio da história quantitativa inúmeros historiadores procuraram traduzir em números muitas das questões acerca da escravidão, particularmente as relativas às condições de vida dos escravos, avaliada a partir de exaustivos dados demográficos, como os da formação de família; considerada pelos autores um importante instrumento para a administração da população cativa e para sua própria organização social no cativeiro. As uniões entre negros e negras consagradas pelo matrimônio, cada vez mais freqüentes no século XIX, e o aumento expressivo dos seus índices de reprodução natural são, de acordo com os referidos autores, dois dos indicadores mais reveladores de uma melhora no tratamento, que os cativos estavam recebendo com os impactos dos debates em torno da abolição do tráfico transatlântico de africanos nos EUA.

O livro deles incentivou um debate intenso sobre diversos aspectos da escravidão. Em relação ao problema da saúde dos escravos, discutiu-se sobre até que ponto os números poderiam revelar uma melhora nas vidas destes indivíduos. Richard Steckel, por exemplo, ao analisar o peso dos negros recém-nascidos nos diários de administração de fazendas do Sul concluiu que em média ele era baixo para os padrões da época, mesmo na primeira metade do século XIX, quando teve ligeiro aumento, o que ajuda a explicar o porquê da alta (embora menos expressiva após o fim do tráfico transatlântico de africanos) mortalidade infantil na população escrava. Em outras palavras, as condições de vida dessa população, ao menos dos situados na base da pirâmide demográfica, haviam melhorado em relação à situação dramática predominante antes da Guerra da Independência, mas ainda não poderiam ser consideradas satisfatórias. ${ }^{9}$

Esse autor mostra, para reforçar o argumento acima exposto, em outro texto publicado em 1986, que as taxas de mortalidade dos recém-nascidos atingiam a absurda cifra de 152 óbitos por 1000 nascimentos em muitas das fazendas por ele estudadas no Alabama, Carolina do Sul, Geórgia e Louisiana, entre 1786 e 1865 a partir de seus diários. ${ }^{10}$ Assim, surgiu-lhe a seguinte questão: se as calorias consumidas pelos 
escravos excedia o mínimo recomendável para restauração da força de um trabalhador braçal, conforme argumentação de Engerman e Fogel no Time on the cross, porque as crianças nascidas no cativeiro apresentavam, em geral, baixo peso? Ele responde: nutrição insuficiente das mães (particularmente em relação à proteína), trabalho durante a gravidez, consumo de álcool e tabaco na gestação, entre outros fatores. ${ }^{11}$

A esse debate dois autores, Philip Coelho e Robert McGuire, acrescentaram um fator (fator patológico) considerado por eles fundamental para explicar o baixo peso dos escravos ao nascerem: duas doenças muito comuns aos escravos, ancilostomíase e malária, que afetavam o desenvolvimento do feto. ${ }^{12}$ Realmente, não se pode negar, em face dos estudos modernos interdisciplinares de nutrição, patologia e genética, que as gestantes mal alimentadas e portadoras de determinadas enfermidades, como as infecciosas ou parasitarias, tendem a dar à luz crianças com peso, altura e resistência insuficientes para padrões aceitáveis. ${ }^{13}$

Em 1978, Savitt Todd publicou Medicine and slavery, considerado um dos melhores estudos sobre história da saúde da população escrava nos EUA. Trata-se de uma pesquisa dedicada a analisar comparativamente as condições de saúde, as doenças e os cuidados médicos com negros submetidos ao cativeiro na Virgínia. Seu autor dedicou-se durante três anos a aprender em uma faculdade de medicina a base do conhecimento médico para começar suas pesquisas nesse campo de estudos. E isso o permitiu a chegar a conclusões baseado em estudos genéticos, seguindo a linha inaugurada pelo historiador Peter Wood, autor de um importante trabalho sobre os negros na Carolina do Sul. ${ }^{14}$ Por exemplo, a de que geneticamente os negros estavam mais predispostos a serem afetados por doenças respiratórias, como a pneumonia (uma das mais incidentes e fatais enfermidades enfrentadas pelos negros em todas as colônias das Américas) porque apresentavam, até o seu contato mais intenso com os brancos e com o clima frio de certas regiões para onde foram deslocados pelo tráfico, baixa imunidade contra os agentes que as causavam. Em contrapartida, resistiram mais contra malária por portarem um gene (G-6 PD), que os protegia dos efeitos mais letais dessa moléstia. ${ }^{15}$ De fato, todos os estudos e todas as fontes médicas e hospitalares da época

11 Ibidem, p 185.

12 COELHO e MCGUIRE (2000).

13 A esse respeito os trabalhos publicados nos periódicos Journal of Nutrition 123, $\mathrm{n}^{\circ}$ 6, 1993 e American Journal An Tropical Medicine And Hygiene, 48, nº 5, 1993.

14 WOOD (1974).

15 TODD (1978). A relação entre genética e doença encontra-se espalhadas pela obra. As páginas 7 a 47 
da escravidão apresentam as doenças respiratórias, ao lado das relativas ao aparelho digestivo, das verminoses e contusões, como um dos problemas de saúde mais comuns e graves no cativeiro. No entanto, essa predisposição dos negros a contraírem moléstias do peito (como eram chamadas genericamente as afecções que afetavam os órgãos do aparelho respiratório naquele tempo) poderia ser neutralizada por alimentação saudável (rica em vitamina C) e por maiores cuidados com a proteção contra o frio durante o inverno, que de modo geral não ocorria, a não ser a partir dos impactos dos debates sobre o fím do tráfico e da própria escravidão e com a maior difusão do saber médico.

No mesmo livro, Savitt Todd, além de apresentar as doenças mais comuns da população escrava (junto das respiratórias, ele elenca as parasitoses, as venéreas e as gástricas e intestinais entre as principais), também analisa os cuidados médicos com a escravaria. Para ele, a tese da negligência senhorial para com a saúde dos negros deve ser relativizada, ao menos na Virgínia (recorte geográfico de seu estudo) porque em muitos diários de fazendas da região ele encontrou anotações relativas a compras de remédios e contratação de médicos para cuidar de escravos doentes, mesmo antes das pressões contra o trabalho escravo e o comércio internacional que o alimentava, quando tais práticas passaram a ser bem mais corriqueiras nas grandes plantações.

Além disso, o autor ainda analisa outro aspecto bastante relevante para história da saúde dos escravizados: as terapias retiradas da sabedoria popular utilizadas em larga escala pelos negros. Segundo ele, mesmo quando um senhor procurava reduzir o custo de manutenção da sua escravaria, evitando contratar médico e comprar remédios, ainda assim restava aos doentes (e muitos até confiavam mais nas soluções tradicionais, geralmente fundamentadas no conhecimento empírico de ervas e minerais) à "farmácia da natureza", cuja oferta era inesgotável para a maioria de indivíduos que vivia na imensa área rural norte-americana.

O seu trabalho despertou grande interesse por ter abordado diferentes assuntos relativos à saúde da população escrava e em profundo diálogo com a medicina, o que permitiu considerável avanço historiográfico a respeito desse tema. Tanto que, a partir dele foi possível fazer balanços comparativos mais precisos sobre as condições de saúde dos escravos norte-americanos, como o de Martin Kaufman que confrontou alguns dos mais relevantes trabalhos sobre tal temática para fazer uma síntese dos consensos acerca 
de algumas das principais questões que a nortearam. ${ }^{16}$

Depois de Medicine and slavery, tantos outros surgiram para investigar os mais variados objetos a respeito da relação entre saúde e escravidão. E como muitos trabalhos já tinham sido desenvolvidos para diferentes regiões norte-americanas, já era possível estabelecer comparações mais aprofundadas entre elas e demais espaços coloniais escravistas, como fez Kenneth Kiple, ao analisar em 1984 o que ele chamou de "história biológica" da escravidão caribenha, partindo da realidade escravista dos EUA. Os mesmos problemas de tratamento e as mesmas doenças também estavam presentes nas mais diversas áreas de grandes plantações do Caribe. Nelas, as doenças pulmonares, como a pneumonia e tuberculose, igualmente figuravam entre as mais mortíferas, ao lado de doenças do sistema digestivo, parasitoses e graves infecções provocadas por enfermidades altamente contagiosas, como a cólera e a varíola. Nelas a medicina aos poucos também foi sendo introduzida nas fazendas, à medida que tal campo de conhecimento foi avançando (com a invenção da vacina contra a varíola) e as pressões iluministas contra a escravidão também foram anunciando o fim da legalidade da importação de africanos.

No entanto, os efeitos demográficos disso não foram tão evidentes nas colônias açucareiras do Caribe quanto nos EUA, pois na primeira região, mesmo com sensível redução na última metade do século de vigência da escravidão, não diminuíram como nas fazendas norte-americanas do Sul, devido a fatores nutricionais (como o consumo de proteína e ferro, que não aumentou suficientemente na dieta caribenha) conjugados com fatores climáticos (as características morfológicas do Caribe proporcionavam uma variação maior de temperatura e um regime de chuvas torrenciais que favoreciam grande incidência de doenças tropicais). ${ }^{17}$

A partir dessa pesquisa outras foram desenvolvidas para a mesma região, com recortes geográficos menores, tendo como referência a realidade dos EUA revelada por diversos autores e a do Caribe revelado por Kenneth Kiple, como a de Richard Sheridam dedicada às "Índias" ocidentais britânicas, na qual mostra entre outras coisas o impacto demográfico positivo da introdução do saber médico na população escrava. ${ }^{18}$

Outra contribuição importante para o avanço da historiografia norte-americana a

16 KAUFMAN (1979).

17 KIPLE (1984) p. 116-8.

18 SHERIDAM (1985). 
respeito dessa tema foi dada pelo conjunto de estudos organizados por Alan Bewll intitulado Slavery, Abolition and Emancipation, publicado em 1999, particularmente o volume 7 da obra: Medicine and the West Indian slave trade. Além de publicar textos médicos dos séculos XVII ao XIX, para divulgar e facilitar o acesso a fontes bastante esclarecedoras sobre a aplicação do saber médico no tráfico e nas fazendas com grande concentração de escravizados, ele também apresenta uma síntese sobre o impacto dessa aplicação na demografia e economia escravistas das colônias inglesas. Em meio a isso, destacou o desenvolvimento da medicina tropical, como meio eficaz de combater doenças típicas dos trópicos e, consequentemente, de redução dos altos índices de mortalidade tanto de escravos quanto de colonos que prejudicavam os interesses da Coroa. ${ }^{19}$

A essa altura, a produção historiográfica norte-americana sobre saúde dos escravos estava bastante avançada, com centenas de textos publicados sobre o assunto e com diversos consensos relevantes, como o do impacto positivo das pressões iluministas e do movimento abolicionista inglês contra a escravidão e o tráfico que a alimentava, o da eficácia da introdução do saber médico no cativeiro e o da importância da intervenção estatal na relação senhor e escravo para impulsionar o aumento da população escrava.

E foi com base em tal produção que estudos com fins políticos e sociais, analisando comparativamente as condições de saúde entre brancos e negros nos EUA, puderam cobrar medidas reparadoras aos infortúnios sofridos pelos africanos e seus descendentes submetidos ao trabalho servil e os seus efeitos de longo prazo na qualidade da saúde dos descendentes da escravidão, sobretudo dos mais pobres. Um dos estudos que seguem essa linha é o de Rodney Hood, que utilizou estatísticas do Department of Health and Human Service (DHHS), confrontadas com as informações historiográficas sobre a situação dos antigos escravos nas fazendas do Sul, para mostrar que continua havendo considerável disparidade em matéria de saúde pública entre brancos e negros, principalmente nos Estados que foram mais apegados à escravidão e apresentam forte presença de racismo. ${ }^{20}$

Mais recentemente surgiram novas pesquisas com objetos bem específicos, ou pontuais, que contribuem muito para ampliar o conhecimento da realidade da saúde da 
população escrava norte-americana. Uma delas é a de Marie Jenkins Schwartz, Birthing a slave: motherhood and medicine in Antebellun South, publicado em 2006. Com o aumento das pressões contra o tráfico no Atlântico-Norte que culminaram na proibição desse comércio em 1807, os preços dos escravos cresceram muito em um momento de ampliação da demanda internacional por algodão. A saída dos grandes produtores rurais foi, além de melhorar as condições de saúde de sua escravaria, incentivar a reprodução natural. Sabe-se que essa medida deu certo, pois a população escravizada dos EUA experimentou tamanho avanço que de aproximadamente um milhão de indivíduos no início século XIX passou para algo em torno de quatro milhões às vésperas da abolição da escravatura naquele país (1865). Uma das razões disso, segundo a autora, foi o desenvolvimento de uma medicina especializada na saúde da mulher, particularmente na saúde reprodutiva. Diversos manuais destinado a esse assunto foram publicados ao longo de tal período e as instituições de ensino médico formaram grande número de obstetras e ginecologistas. Nos diários de fazendas ela encontrou para todas as excolônias do Velho Sul a contratação de profissionais com essas especialidades para cuidar das gestantes antes, durante e depois do parto, bem como de suas crianças no seu período mais crítico de vida (os primeiros meses,) revelando que os procedimentos médicos do pré-natal foram cada vez mais comuns, sistemáticos e benéficos para a redução da mortalidade das escravas e de seus filhos. Revelou também que houve grande interesse dos médicos em estudar doenças femininas, principalmente as relacionadas com o aparelho reprodutivo, como os tumores, para os quais ela dedicou um capítulo inteiro (o oitavo), e mostrou como todas essas novas cautelas eram divulgadas exaustivamente pelos mais diversos periódicos agrícolas destinados aos fazendeiros. Trata-se de um estudo que somente poderia ser feito em um país com enorme tradição em estudos escravistas e com a disponibilidade de farta, rica e variada documentação, como os abundantes e detalhados diários de fazendas, que permitem o historiador conhecer a fundo a sua experiência histórica em um assunto tão delicado. ${ }^{21}$

No início de 2013 Caitlin Rosenthal prometeu a publicação de um livro intitulado From slavery to scientific management: capitalism and control in America (1754-1911), no qual ela investiga o gerenciamento do trabalho, os incentivos para a produção e os recursos para estimular a produtividade, e os encontra em muitas grandes propriedades escravistas norte-americanas, principalmente nas fazendas do Sul, 21 SCHWARTZ (2006) p. 13, 31 e 105. 
argumentando que o capitalismo não os inventou e sim os aprimorou. Em meio a isso, mostra o quanto as boas condições de saúde dos escravos, possibilitadas entre outras coisas pela inserção cada vez maior do saber médico na administração da mão de obra cativa, foram fundamentais para o sucesso da economia escravista do país. Embora esse argumento não seja novidade, a sua utilização em um novo contexto explicativo (o da eficácia de incentivos aos trabalhadores para melhorar a qualidade e quantidade da produção) revela o quanto o controle das doenças foi decisivo para impulsionar a prosperidade dos empreendimentos e da economia nacional, ecoando a síntese lapidar de Benjamin Franklin (1706-1790), em sua paráfrase da obra máxima de Adam Smith: "A saúde é a riqueza das nações." 22

Diante dessa breve exposição de alguns dos mais relevantes estudos sobre a saúde da população escrava dos EUA (uma pequena amostra do universo enorme da produção historiográfica norte-americana) pode-se concluir que a historiografia desse país sobre esse assunto, por ser tão avançada, permitiu até o embasamento de estudos de natureza política, como o do acima citado Rodney Hood, para pressionar a Federação a intervir numa disparidade histórica que, mesmo com o fim da escravidão, persiste em muitos de suas localidades.

Esse avanço ainda está longe de ser atingido por nós. E isso talvez seja efeito do fato de o conhecimento histórico acadêmico brasileiro ter se desenvolvido muito tarde e lentamente em relação ao dos EUA. Afinal, a moderna historiografia brasileira somente foi inaugurada entre as décadas de 1930 e 1940, com a publicação e repercussão de três dos seus maiores clássicos: Casa-grande e senzala (1933) de Gilberto Freyre, Raízes do Brasil (1936) de Sérgio Buarque de Holanda e Formação do Brasil contemporâneo (1942) de Caio Prado Jr, ${ }^{23}$ quando a organização do ensino profissional e da pósgraduação em história estava sendo ainda iniciada. Acrescente-se a isso o fato de que entre a conclusão dessa organização e a consolidação do amadurecimento da pesquisa histórica no país, com a formação de uma geração de arquivo a partir de finais dos anos 1970 (isto é, que abandonou a tendência até então predominante de estudos interpretativos respaldos na maioria das vezes apenas em fontes primarias transcritas em

22 A referida obra de Adam Smith é $A$ riqueza das nações publicada originalmente em 1776.

$23 \mathrm{Um}$ dos decanos da intelectualidade brasileira que considera tais clássicos a tríade fundadora da moderna historiografia e sociologia em nosso país é Antônio Cândido. Tais considerações ele teceu no prefácio das edições de Raízes do Brasil elaboradas pela Cia das Letras, na de 1997 por exemplo. Consideração análoga é feita por MOTTA (2008) p. 69-72. 
revistas especializadas, como a do IHGB), decorreu tempo insuficiente para ampliação de oferta de historiadores que pudessem investir em pesquisas tão tematicamente variadas e necessitadas de uma base historiográfica ainda então em construção. ${ }^{24}$ Diante desse quadro, eles optaram pelo esforço de responder a questões mais básicas de nossa história nacional, para posteriormente tentar alargar o seu horizonte de estudo, o que vem ocorrendo desde o final dos anos 1980 em ritmo acelerado.

Por essa razão, antes do final da década de 1970, quando os historiadores começaram a lidar mais diretamente com o tema em discussão, havia pouca coisa disponível para o seu entendimento. Um deles é o livro do médico Octávio de Freitas, Doenças africanas no Brasil, publicado em 1935, no qual, ao descrever causas de diversas enfermidades mais comuns dos negros, defende a hipótese de que um dos principais males da escravidão foi o de trazer, junto com os escravos, uma série de patologias estranhas ao país que muito contribuiu para agravar a sua constituição nosológica, tornando-o mais insalubre. ${ }^{25}$

Sua hipótese, fundamentada em uma visão racial e naturalizada da doença, tem sido bastante criticada por autores responsáveis pelo surto historiográfico sobre tal tema no Brasil na última década, como Diana Maul de Carvalho, que condena tal visão por nela estar embutida a ideia de um paraíso degradado pela colonização, conforme sugere o título do primeiro capítulo de Octávio Freitas "Bons ares; maus colonos"; ideia falsa, responsável pela construção de um entendimento deturpado da história biológica e dos povoadores espontâneos e forçados da Colônia, porque ignora o fato de que a disseminação de uma enfermidade "exportada" depende de condições naturais préexistentes do território onde ela é inserida e das formas de interação entre seu portador e o meio, conforme esclarece a referida autora. ${ }^{26}$

Outro estudo dedicado ao tema, mas não de forma exclusiva, é o livro de Gilberto Freyre, Os escravos nos anúncios de jornais brasileiros do século XIX, publicado em 1963. Esse autor buscava dados, em fontes até então pouco utilizadas para o estudo da escravidão, para conhecer o cotidiano dos escravos e algumas de suas características sociais. Com essa inovação metodológica, ele recuperou muitas informações sobre a vida dos negros submetidos ao cativeiro, entre elas, marcas ou

24 Para uma análise da formação da historiografia brasileira recomendo MOTTA(2008).

25 FREITAS (1935) p. 18-20.

26 CARVALHO. In: PORTO (2007), p. 6. 
sintomas de doenças ou ferimentos que pudessem ajudar a identificar escravos fugidos. Com esse tipo de informação, foi possível fazer um quadro dos problemas de saúde mais evidentes nos corpos dos fugitivos e, com isso, conhecer alguns indicadores das condições de vida no cativeiro.

Seguindo o seu método, Márcia Amarantino elaborou uma pesquisa, nas edições de 1850 do Jornal do Comércio, para conhecer os mesmos indicadores relativos à realidade da capital do Império no auge da escravidão no Brasil. Dos 409 anúncios observados (como o seguinte: “\$500 se dará de gratificação a quem levar ao dar notícia ... de um preto de nome Pedro, nação rebolo, sem barba, estatura regular, com sarnas pelos braços") ela descobriu que os problemas mais identificados nos corpos dos fugitivos anunciados são doenças infecciosas $(34,96 \%)$ e traumáticas $(30,58 \%){ }^{27}$

Depois do estudo Gilberto Freyre, somente na segunda metade da década de 1970 que outras pesquisas começaram a surgir. Uma delas foi conduzida por Iraci del Nero da Costa dedicada à análise da morbidade em Vila Rica entre 1799 e 1801. Essa análise foi feita a partir dos assentamentos de óbitos registrados na Paróquia de Nossa Senhora da Conceição da antiga e populosa freguesia de Antônio Dias. Segundo seus cálculos, a mortalidade da população escrava girava em torno de $20 \%$ e era $76 \%$ maior em relação à dos livres, com destaque alarmante para a mortandade infantil (238 mortes por 1000 nascimentos, sendo 31,42\% delas ocorridas no primeiro mês de vida e 37,15\% ocorridas entre dois meses e um ano de vida). Em relação às doenças mais comuns, observou que as doenças do aparelho respiratório, principalmente tuberculose e pneumonia, foram as mais mortíferas, seguidas pela hidropisia e gangrenas. ${ }^{28}$

Sua pesquisa, embora baseada em um curto recorte cronológico e em apenas uma localidade de Vila Rica, traz importante contribuição dos indicadores das condições de saúde da população escrava em uma antiga área mineradora. No entanto, depois de mais de três décadas da publicação original do seu trabalho, ainda não sabemos se os dados obtidos por ela entre 1799 e 1801 dizem respeito à apenas esse biênio e à mencionada freguesia, ou se pode ser generalizado para todo o período e espaço colonial mineiro, devido à ausência de estudos complementares para essa região.

Em 1978, na coletânea organizada por Roberto Machado, foi publicado um

27 AMARANTINO (2007). O anúncio encontra-se na p. 1382 e os dados tabulados em percentuais das doenças mais visíveis nos corpos dos escravos, segundo os anunciantes, estão na p. 1384.

28 COSTA. In: LUNA (2009). O artigo foi publicado originalmente em 1976. Os dados acima apresentados estão, respectivamente nas páginas 243, 247 e 250. 
capítulo avaliando a preocupação médica e governamental sobre a saúde da população escrava, usando como estratégia de abordagem o levantamento de textos dedicados ao assunto. Como seus autores encontraram pouquíssimos, concluíram que esse tema não era relevante nas reflexões médicas da época em que vigorou a escravidão. ${ }^{29} \mathrm{Tal}$ capítulo teve o mérito de iniciar uma discussão relevante sobre a história intelectual da medicina dedicada ao cativeiro e de divulgar fontes médicas muito ricas sobre a história da saúde dos cativos, que acabaram sendo usadas para os mais diversos fins na historiografia especializada no campo de estudos em pauta. E essa sua conclusão manteve-se quase inquestionada enquanto novas pesquisas não foram desenvolvidas, ou seja, por longo tempo.

Porém, no recente impulso aos estudos sobre a saúde dos escravos, promovido pelos pesquisadores identificados com os objetos de pesquisa do campo historiográfico conhecido como história da saúde, da doença e da medicina, há pouco tempo consolidado no Brasil, surgiu o trabalho de Silvio Cezar de Souza Lima: $O$ corpo escravo como objeto das práticas médicas no Rio de Janeiro (1830-1850). Trata-se de uma tese defendida em 2011, no programa de pós-graduação em história das ciências e da saúde da Fundação Oswaldo Cruz, que mostrou que, apesar de haver pouca publicação médica dedicada diretamente à saúde da população cativa, esse tema não pode ser considerado secundário nas reflexões médicas, pois em muitas edições de periódicos e teses de medicina há incontáveis exemplos de análise médica sobre moléstias dos cativos. Mais do que refutar o mencionado trabalho inserido na coletânea de Roberto Machado, o autor revela o quanto, involuntariamente, o corpo escravo foi fundamental para a construção do saber médico brasileiro, ao ser investigado nas suas instituições imperiais de ensino e pesquisa. ${ }^{30}$

Em 1979 Douglas Cole Libby defendeu a sua dissertação intitulada Trabalho escravo na mina de Morro Velho. Grande parte de sua pesquisa foi destinada a analisar as condições de vida, trabalho e saúde dos escravos em um complexo aurífero, localizado na antiga Nova Lima-MG, pertencente à companhia inglesa Saint John del Rey Mining Company. Embora seu objetivo maior é o de mostrar que a escravidão não foi incompatível com o capitalismo em tal empreendimento, ao revelar que o trabalho

29 MACHADO (1978) p. 370.

30 LIMA (2011). A crítica do autor ao estudo de MACHADO (1978) encontra-se na p. 2 e uma síntese de seu principal argumento está entre as páginas 148-149 e 190 -192. 
escravo era mais lucrativo (em termos de mais valia absoluta) do que o assalariado, ele dá importante contribuição ao estudo das condições de saúde da população escrava, ao descrever a rotina de trabalho, da vida e da salubridade na mina de Morro Velho, analisando o empenho de seus administradores para reduzir a mortalidade escrava em tal mina.

O ensaio elaborado por esse autor a respeito das condições de saúde dos escravos da mina de Morro Velho ainda não havia sido revisto e aprofundado até a publicação deste presente livro, devido ao fato de nossa historiografia sobre tal tema ter sido impulsionada apenas recentemente. ${ }^{31}$ Por isso, senti-me motivado a enfrentar documentação produzida pela Saint John del Rey Mining Company (de difícil leitura por se tratar de inglês oitocentista), e empreendi uma análise inspirada no estudo do governo dos escravos nas Américas, elaborado por Rafael de Bivar Marquese, objetivando comparar as conclusões desse autor para as propriedades rurais com um empreendimento urbano. ${ }^{32}$

Assim, com base nos relatórios que os administradores daquela mina enviavam para Londres anualmente e no estudo pioneiro de Douglas Cole Libby, inicialmente observei, no penúltimo capítulo deste livro, que (depois de pressões dos abolicionistas de seu próprio país, da dificuldade prevista de adquirir mão de obra escrava com os debates em torno do fim de fato da importação de africanos para o Brasil nas vésperas de1850 e dos conselhos divulgados por letrados e médicos a respeito do manejo mais eficaz da população cativa) em Morro Velho houve grande esforço para se colocar em prática um conjunto de preceitos, há muito tempo conhecidos, mas até então pouco praticado, que acabaram contribuindo para disciplinar o enorme contingente de trabalhadores servis e reduzir a sua mortalidade. Entre os preceitos encontra-se a utilização do saber médico para preservar preventivamente ou restaurar a saúde dos escravos, com a contratação de médicos e enfermeiras, a construção de um hospital e a elaboração de quadros estatísticos anuais para se conhecer as doenças que mais afetavam a mão de obra, com o objetivo de combatê-las.

310 estudo elaborado por CHILDS (2002) ao abrigo da Universidade da Carolina do Sul, EUA, embora toque na questão, o faz sem avançar o estudo de LIBBY (1979), uma vez que seu foco é a análise dos rituais que envolviam as relações de poder entre senhores e escravos, conforme expresso no título de seu trabalho, o qual foi um dos primeiros a divulgar imagens da escravidão na mina de Morro Velho. 
A eficiência do capitalismo britânico, sua longa experiência com a escravidão em outros espaços coloniais e a reforma na forma de governar os escravos fizeram alguma diferença na demografia destes indivíduos em Morro Velho? Em parte sim, pois os índices de mortalidade na mina eram um pouco menos aterradores quando comparados com estatísticas do século XVIII, mas a baixa fertilidade das escravas e a mortalidade infantil não permitiriam a população escrava crescer naturalmente como ocorreu nos EUA.

Em 1982, Maria das Mercês Somarriba publicou sua dissertação Medicina no escravismo colonial. Nela reiterou a tese de Roberto Machado, de que havia uma quase inexistência de uma reflexão médica sobre a saúde dos escravos, e se propôs "avançar na explicação para a não existência, em escala significativa pelo menos, de uma medicina do escravo e de uma política de saúde voltada especificamente para a mão de obra escrava".

Usando o conceito de escravismo colonial de Jacob Gorender, ela apoiou-se em uma das principais lógicas do escravismo apontadas por esse autor (a de que quanto mais alta a rentabilidade conjuntural da produção escravista no mercado, tanto mais vantajoso estafar o escravo para obter dele o máximo de sobreproduto em curto prazo) para explicar os altos índices de mortalidade da população cativa. Até aí ela contribui para a compreensão da lógica senhorial empregada na administração de sua escravaria.

Em outros termos, ela mostra que algumas variáveis, como preço do trabalhador servil, rentabilidade e a capacidade de trabalho dele, foram fundamentais para determinar o comportamento senhorial em relação a aspectos que muito influenciavam a saúde no cativeiro, como o tempo de trabalho exigido dos indivíduos a ele submetidos. Afinal, no cálculo dos senhores, muitas vezes era mais lucrativo substituir um negro desgastado por excesso de horas de trabalho, do que encurtar a sua jornada e fazer investimentos adicionais para prolongar sua vida produtiva.

Assim, quando tal lógica se impunha em determinados contextos, não havia lugar para preocupação mais profunda e sistemática com a saúde dos escravos, o que explica, na visão da autora, a quase ausência de interesse médico na abordagem intelectual de temas a isso ligado; interesse que, segundo ela, somente ocorreu a partir do fim do tráfico transatlântico de africanos para o Brasil e da ampliação da demanda externa pelos seus produtos agrícolas, notadamente o café. ${ }^{33}$

33 SOMARRIBA (1982). A lógica do escravismo colonial gorendiana da qual ela se vale encontra-se nas 
Esse estudo, apesar de corroborar uma tese (a de Roberto Machado acima sintetizada) recentemente contestada pelo citado estudo de Silvio Cezar de Souza Lima, é de grande importância por ter sido o primeiro a utilizar a lógica da rentabilidade dos empreendimentos coloniais para explicar o porquê das condições de saúde dos escravos terem sido tão ruis de um modo geral. E também por ter sido o primeiro estudo que mostrou uma tendência de mudança em tais condições ao final da importação de negros para o Brasil, revelando novas fontes de estudo (manuais de medicina prática especializados em doenças de escravos) para outras questões relativas a esse tema. Mesmo com toda essa contribuição, seu trabalho foi quase ignorado pelos historiadores da escravidão e quase não é citado pelos que promoveram esse surto historiográfico sobre o tema em análise; sintoma do caráter incipiente e de algumas fragilidades da historiografia brasileira sobre esse tema.

Outro estudo relevante relacionado com o mesmo tema foi publicado por Pedro Carvalho de Mello em 1983, dedicado ao exame da estimativa da longevidade dos escravos na segunda metade do século XIX. Seu ponto de partida historiográfico é o debate sobre a Abolição após a promulgação da Lei do Ventre Livre. Uma das controvérsias, entre emancipacionistas (os grandes fazendeiros eram seus principais protagonistas) e abolicionistas, a respeito do processo gradual do fim da escravidão, girou em torno da seguinte questão: haveria a necessidade de medidas adicionais para acelerar esse processo? A resposta que conduziria a decisão do Estado dependeria da quantidade média de vida produtiva dos escravos. Sabe-se que os abolicionistas venceram o debate, levando o governo imperial a aprovar leis que culminaram na Lei Áurea (13 de Maio de 1888). O argumento principal dos vitoriosos foi o de que as melhorias das condições de saúde poderiam prolongar a longevidade da população cativa, estendendo dessa maneira o trabalho servil por muito mais tempo além do tolerável.

Partindo dessa controvérsia, o autor procurou analisar as fontes demográficas e os testemunhos de estimativas de vida da escravaria para investigar qual era de fato a sua expectativa de vida. Com isso, acabou observando alguns indicadores (sobretudo o de mortalidade e fertilidade) que permitem avaliar as condições de saúde dos escravos. Sua principal fonte é o Censo de 1872, no qual encontrou resultados que o levaram a 
concluir que, entre 1850 (data do fim do tráfico transatlântico de africanos para o Brasil) e o ano do referido Censo, a fertilidade e a longevidade escrava não aumentaram significativamente. Pois, como entre uma data e outra havia transcorrido pouco mais de 20 anos, o impacto da extinção do tráfico no cálculo econômico dos senhores não teve tempo suficiente para operar seus efeitos no investimento da reprodução natural da população cativa, e, com decreto da Lei do Ventre Livre (1871), que possivelmente freou os ânimos dessa investida, não se poderia esperar que houvesse alguma melhora naqueles indicadores. ${ }^{34}$

Sem julgar o mérito dessa conclusão (pessimista demais, uma vez que no intervalo das duas datas acima citadas, 22 anos, havia 611451 escravos de 0 a 19 anos), os dados gerais daquele censo mostram que a demografia escrava tinha condições de crescer naturalmente (sobretudo porque havia considerável equilíbrio entre os sexos, e mais 277139 escravos entre 20 e 29 anos), caso outras condicionantes (principalmente os ligados à saúde) favorecessem e a Lei do Ventre Livre não existisse.

Embora tendo lidado com tema em exame indiretamente, preocupado com um problema da história demográfica, o estudo de Pedro Carvalho de Mello mostra que houve melhorias nos indicadores de saúde no cativeiro após 1850, e mesmo que se para ele a melhora não tivesse sido a ideal, devido ao pouco tempo para a produção dos efeitos do fim do tráfico, está implícito na sua conclusão que havia uma tendência nesse sentido, a qual foi freada inicialmente em 1871 e posteriormente com a vitória dos abolicionistas em relação à aceleração do processo gradual do fim da escravidão.

Enquanto os historiadores brasileiros ainda estavam lidando com a saúde dos escravos apenas eventualmente e, na maioria das vezes, de maneira indireta, uma das mais esclarecedoras pesquisas sobre esse tema foi desenvolvida por Mary Karash ao abrigo da Universidade de Princeton, onde foi publicada em 1987. Focada no Rio de Janeiro entre 1808 e 1850, ela dedicou três longos capítulos ao estudo de aspectos demográficos e das condições de vida, trabalho e saúde da população escrava.

As suas principais conclusões sobre o assunto foram as seguintes: 1) as taxas de óbitos dos negros submetidos ao cativeiro, principalmente a infantil, eram ainda muito altas; 2) as doenças mais mortíferas em tal população eram as mesmas que dos EUA e da Europa (as infecto-parasitárias, seguidas pelas gastrointestinais e pelas respiratórias), sendo as mais comuns, nessa ordem, a tuberculose, disenteria, diarreia, gastroenterite, 34 MELLO (1986) p. 162-163. 
pneumonia, varíola, hidropisia, hepatite, malária e apoplexia.

Assim, ela pode afirmar:

\begin{abstract}
"Os historiadores tenderam a culpar as moléstias tropicais pela alta mortalidade de escravos no Brasil, mas o material da Santa Casa contesta, ao menos para a cidade do Rio de Janeiro, a suposição de que essas moléstias sozinhas dizimavam a população escrava, ou que os donos de escravos pouco podiam fazer para preservar sua propriedade diante de doenças endêmicas e epidêmicas (...). Exceto a malária e a varíola, que não respeitavam posição social, as outras doenças podem refletir os baixos padrões socioeconômicos de vida da população escrava. Em outras palavras, os escravos morriam em maior número de moléstias cuja incidência diminui à medida que os padrões de um grupo populacional melhoram. [Assim] o resultado era uma inevitável despovoação dos escravos." 35
\end{abstract}

Suas conclusões revelam que, no Rio de Janeiro da primeira metade do século XIX, a vida do escravo era, do ponto de vista da saúde, muito ruim. Por isso continuavam morrendo em grande quantidade e por causas na maioria das vezes evitáveis, resultando numa dramática despovoação que somente foi impedida pela reposição de novas importações de africanos.

Como o recorte cronológico da autora compreende o período de intensa atividade do tráfico negreiro internacional na capital do Império, dificilmente se poderia esperar outra realidade, dada a fartura de negros ofertada quase sem interrupção por essa modalidade comercial. Dessa maneira, os dados encontrados por Mary Karash indicam que os grandes proprietários ainda continuavam motivados pela lógica econômica colonial de maximização da exploração do trabalho escravo, com o menor custo, visando à satisfação da ampla e crescente demanda externa por monocultura e ao aumento de sua rentabilidade.

Depois desse passo decisivo na historiografia da saúde dos indivíduos submetidos à escravidão dado pela referida autora, veio a público em 1988 um artigo da pesquisadora Ângela Pôrto, dedicado ao estudo da assistência médica a tais indivíduos, que apresenta informações muito importantes para a compreensão do tema em discussão. Uma delas é a criação de uma companhia de seguros, a Cia União, em 1845 na cidade do Rio de Janeiro, cujos serviços foram contratados já no seu primeiro ano de funcionamento por uma centena de proprietários.

35 KARASH (usarei a versão brasileira de 2000) p. 258. 
Com essa descoberta ela abriu caminho para relativizar a ideia corrente entre os historiadores de que os grandes senhores eram de um modo geral negligentes com a saúde dos escravos. Pelo menos na capital do país, em meados da última década de vigência do tráfico transatlântico de africanos para o Brasil, o seu trabalho mostra indicadores, como o acima revelado, de que havia centenas de fazendeiros que mostravam grande preocupação com seu investimento em mão de obra compulsória. Afinal, no caso de morte de escravo o seguro não era pago se ela ocorresse por maus tratos e descuido em matéria de saúde. ${ }^{36}$

Durante quase duas décadas após a publicação do seu artigo, a autora retornou ao assunto com textos ora de caráter historiográfico, ${ }^{37}$ ora de divulgação de documentos, ou de apresentação de novas pesquisas, como a coletânea intitulada Doenças e escravidão: Sistema de saúde dos escravos no Brasil do século XIX, organizada ao abrigo da Fundação Oswaldo Cruz e publicada em 2007.

Essa coletânea pode ser considerada um marco importante do processo de construção de uma historiografia especializada no tema em análise, ao promover pela primeira vez a reunião de tantos estudos direta e indiretamente ligados a ele que vale como um esforço inicial de síntese, a qual será melhor avaliada mais adiante. Antes é necessário retornar à década de 1990 e recuperar contribuições de mais duas pesquisas relevantes que a antecederam.

A primeira delas é a da professora Ilka Boaventura Leite, que investigou aspectos da vida de escravos e libertos em Minas Gerais do século XIX, a partir dos relatos de viagem dos "viajantes" em uma pesquisa publicada em 1996. Embora esses relatos compõem uma fonte muito controversa, ainda assim ela procurou abordá-la em busca das percepções dos seus autores sobre a realidade da escravidão na maior região escravista do país. E encontrou impressões diferentes entre eles sobre os mesmos objetos, como o tipo, a qualidade e a quantidade de alimentação dada os escravizados. Não obstante, seus relatos lhe serviram para, em um capítulo, examinar a vida cotidiana no cativeiro: dieta, vestimenta, trabalho, folga e saúde foram os itens examinados. Em relação a esse último, ela recuperou nos textos dos viajantes (no total de 18) suas observações sobre as doenças mais comuns dos negros e montou um quadro das que mais foram por eles abordadas. Dessa forma, proporcionou um conjunto de dados,

36 PÔRTO (1988) p. 9.

37 Entre os textos historiográficos por ela publicados, destaque-se o publicado em 2006. 
muito útil para confrontar com outras percepções (dos médicos e das autoridades públicas, por exemplo) para ampliar a compreensão do quadro nosológico da população cativa. ${ }^{38}$

No mesmo ano Sidney Chalhoub publicou um estudo sobre cortiços e epidemias na capital do Império, no qual abordou algumas questões relativas à saúde dos escravos. Uma delas diz respeito ao problema da identificação das classes pobres com determinados problemas, na ótica das elites, que as faziam ser percebidas como classes perigosas. Um desses problemas era a proliferação de doenças epidêmicas, consideradas oriundas das suas moradias e de seu rústico estilo de vida avesso ao ideal sanitário, que então servia de justificativa às políticas públicas antipopulares na segunda metade do século XIX e início do XX, como a derrubada de cortiços e vacinação obrigatória.

No caso das políticas de saúde pública, nesse contexto de expulsão dos pobres (a maioria de negros) para longe do centro da cidade que então se pretendia "civilizar" e de incentivo à imigração europeia, para substituir os escravos e ampliar a oferta de trabalhadores no incipiente mercado de trabalho assalariado nacional, houve também, segundo o autor, um deslocamento do foco governamental e médico para as doenças que mais poderiam afetar os imigrados do que os escravos remanescentes. ${ }^{39}$ Dessa forma, ele revela: 1) uma relação entre racismo, doença e sanitarismo que ajudou a tornar o Rio de Janeiro muito mais socialmente explosivo nas últimas décadas do Império e no início da República; 2) um descaso público para com a saúde da população escrava, incentivado pela Lei do Ventre Livre e pela enorme quantidade de imigrantes que começaram a vir para o país.

Até o fim do século passado, nos estudos sobre saúde dos escravos predominaram abordagens que lidaram com esse tema de forma indireta (isto é, sem tomá-lo como objeto central de investigação) e, mesmo assim, não eram abundantes, conforme vários autores que se empenharam na elaboração de balanços historiográficos específicos sobre esse assunto já observaram. ${ }^{40}$

Daí em diante a realidade historiográfica começa a mudar, pois, além da continuidade dos estudos indiretos, há um surto de pesquisas dedicadas diretamente sobre tal tema que vem aumentado consideravelmente a compreensão dos objetos a ele

38 LEITE (1996). O referido quadro está na p. 170.

39 CHALHOUB (usarei a edição de 1999) p. 92-96.

40 PÔRTO (2006) p. 1024 e BARBOSA e GOMES (2008) p. 237. 
ligados. Entre 2001 e 2003, quando iniciei meu interesse pelo assunto, publiquei dois artigos sobre a tradução publicada em Lisboa em 1801 feita pelo cirurgião Antônio José Vieira de Carvalho, atuante em Vila Rica, do manual médico de Jean Barthelemy Dazille, atuante em São Domingos, Observações sobre enfermidades de escravos, publicada em Paris em 1776.

Foi minha estreia. Havia percebido que os poucos estudos que usaram esse manual não se debruçaram sobre as razões pelas quais ele foi traduzido e o porquê de ambas as monarquias terem patrocinado as suas publicações. E descobri que não se tratava de apenas um esforço para divulgar conhecimento útil para a prosperidade colonial, como interpretou Maria das Mercês Somarriba. ${ }^{41}$ Era também uma forma de responder aos apelos humanitários dos iluministas e de demais críticos à escravidão para que se melhorasse a vida dos escravos, a começar cuidando melhor da saúde deles. Pude aprimorar essas conclusões em 2009, depois de alguns anos de experiência com esse objeto, em outro artigo em que procurei aprofundar a compreensão do sentido histórico da publicação do referido manual e de outros do mesmo gênero no Novo Mundo, aproveitando as contribuições da pesquisa de Rafael de Bivar Marquese, sobre a qual passo a falar a seguir, e explorando algumas de suas lacunas. ${ }^{42}$

O seu estudo trilhou os caminhos da história intelectual para abordar os conselhos e debates em torno do governo dos escravos nas Américas, entre os séculos XVII e XIX, usando textos de diversos campos de conhecimento (agronômico, jurídico, médico, teológico, entre outros) para analisar o processo histórico das formas de concepção da escravidão e os meios mais eficazes da administração do cativeiro. Em relação a esse último ponto, um dos documentos mais interessantes de seu trabalho são os manuais escritos por fazendeiros ou seus prepostos. Neles há um conjunto de medidas destinadas a tornar a produção escrava mais eficiente. Uma delas é a melhora na forma do tratamento dos escravos, incluindo nisso maior cautela para com a saúde deles. No caso do Brasil, ao fazerem propostas dessa natureza, seus autores buscavam, entre outras coisas, responder às pressões internas (como a formação do quilombo de

41 SOMARRIBA (1982) p. 14.

42 Os artigos inaugurais a que me refiro foram publicados nas seguintes revistas: Varia História; revista do depar tamento de história da UFMG $\left(2000, \mathrm{n}^{\circ} 23\right)$ e História Social; revista do departamento de história UNICAMP (2003, $\mathrm{n}^{\circ}$ 10). O artigo de 2009 foi publicado na Varia História; revista do departamento de história da UFMG (2009, $\mathrm{n}^{\circ}$ 41). Em 2010, também publiquei outro texto, discutindo as condições de saúde dos escravos no Brasil do século XIX, Afro-Ásia; revista do centro de estudos afro-orientais da UFBA (2010, $\left.\mathrm{n}^{\circ} 41\right)$. Esses dois últimos estão republicados neste livro. 
Palmares) e externas (a Revolução do Haiti), bem como às críticas contra o tráfico de africanos e às exigências de maior eficiência econômica. Assim, seguindo a tendência intelectual em curso no Ocidente, procuraram mostrar para os grandes proprietários rurais como era possível atender à crescente demanda por produtos agrícolas, explorando a escravaria de uma forma que ela não fosse desgastada predatoriamente e se reproduzisse naturalmente. ${ }^{43}$

Lendo esse inovador estudo fica, porém, uma dúvida: o ideal de administração da população escrava, promovido pelos letrados que lidaram com o assunto, foi seguido pelos proprietários dos grandes empreendimentos das décadas finais do Império? Ou, colocada em outros termos, as condições de saúde dos escravos melhoraram quando se tentou implantar tal ideal? Foi o que tentei responder no penúltimo capítulo deste livro para o caso da Mina de Morro Velho.

No ano de 2004 ainda surgiram mais dois estudos a respeito desse tema. Um deles é o de Miridan Britto Falci dedicado às doenças de escravos em Vassouras. Investigando principalmente documentação seriada, com ênfase nos inventários de bens, a autora elaborou um quadro estatístico com indicadores demográficos que ajudam a avaliar as condições de saúde da população escrava de tal próspero município cafeeiro do Vale do Paraíba Fluminense e os males que mais a afetavam. E por ele pôde concluir que os indivíduos dessa população no município enfrentavam as mesmas dificuldades de outras regiões, apresentando nível de mortalidade tão alto e incidência de moléstias de mesma natureza que demais regiões já conhecidas. ${ }^{44}$

Esse estudo aponta para uma tendência (a de produção de estudos com recortes geográficos concentrados em cidades, ou em um de seus distritos, necessários para ampliar análises comparativas) que se for consolidada contribuirá para ampliar o entendimento historiográfico sobre as generalidades e particularidades da vida que os escravos levavam nos cativeiros deste vasto país e as enfermidades que mais os atacavam.

Seguindo essa tendência alguns estudos já foram concluídos, como os publicados em 2009 e 2010 por Carolina Bitencourt Becker, Jaqueline Hans Brizola, Natália Pinto e Paulo Roberto Staudt Moreira dedicados a cidades de Rio Grande, Alegrete e Porto Alegre, nos quais mostram como eram as condições de saúde no

43 MARQUESE (2004) p. 284.

44 FALCI (2004) p. 24. 
cativeiro em tais cidades (ruins de um modo geral) e quais doenças mais os afetavam (as mesmas já conhecidas, mais ou menos na mesma ordem de importância encabeçadas pelas infecciosas, em particular as que afetavam o aparelho respiratório). ${ }^{45} \mathrm{Um}$ desses estudos, por exemplo, mostra que, diferentemente do que se pensava, a maioria dos cativos internados na Santa Casa era composta por uma faixa etária dos 12 aos 35 anos entre as vésperas do fim do tráfico em 1850 e os primeiros anos posteriores, com um percentual que variou entre 57 e $64 \%$, o que mostra que o hospital não era uma sala de espera para o cemitério e que e muitos senhores pagavam para recuperar a saúde de seus negros (afinal a Santa Casa somente atendia de graça as pessoas pobres de condição livre e alforriada). ${ }^{46}$

Retornando a 2004, nesse ano foi publicada o volume inaugural de Uma história brasileira das doenças, no qual há um capítulo dedicado ao estudo da saúde dentária dos escravos em Salvador assinado por três autores. Além de inovarem em relação ao objeto, também usaram um recurso metodológico novo em termos de estudo historiográfico sobre o tema no Brasil: a paleopatologia, que consiste em estudar os vestígios de doenças em fósseis. Nesse caso, investigaram esqueletos de escravos exumados da Igreja da Sé, e descobriram que muitos deles apresentavam doenças bucais das mais variadas, provenientes de baixa ou nenhuma profilaxia, e grande incidência de cárie provocada possivelmente pelo maior consumo de açúcar de trabalhadores servis de uma região açucareira. ${ }^{47}$ Trata-se de uma inovação que demanda um diálogo intenso entre campos científicos diferentes, cuja aproximação e esforço conjunto poderão dar grandes contribuições ao esclarecimento sobre os problemas mais enfrentados pela população escrava na longa época do cativeiro. ${ }^{48}$

Em 2006, outro volume com igual título trouxe em suas páginas o artigo de Betânia Gonçalves Figueiredo, As doenças de escravos: um campo de estudo para a história da doença e a da saúde. Texto de natureza historiográfica, com sugestões de pesquisa para avançar esse tema considerado pela autora pouco explorado, apresenta algumas considerações a cerca da sua história. Uma das mais esclarecedoras é a de que os cuidados para combater as doenças da população cativa não eram motivados apenas

45 BRIZOLA (2010) e BECKER (2010).

46 BRIZOLA (2010) p. 37.

47 SILVA et Al. In: NASCIMENTO e CARVALHO (2004).

48 A propósito, agora pouco foi descoberta uma fazenda no sul de Minas, no município de Machado, mantenedora de um cemitério de escravos, que está sendo investigado por uma equipe de pesquisadores com a qual colaboro, com resultados iniciais esperados para breve. 
pela necessidade de manutenção da força de trabalho, mas também pelas exigências das transações comerciais que envolviam cativos. Conforme suas próprias palavras, "escravos com boas condições de saúde vão atingir um preço no mercado distinto daqueles combalidos fisicamente". ${ }^{49}$ Essa hipótese faz sentido muito mais para os comerciantes de trabalhadores servis (inclusive, havia pessoas especializadas em comprar escravos doentes, por preços irrisórios, para tentar recuperar sua saúde e recolocá-los no mercado) do que para os senhores, uma vez que estes normalmente não adquiriam negros para negociá-los. Todavia, quando a necessidade de envolvê-los em negociações se impusesse, não resta dúvida de que uma das primeiras precauções dos seus proprietários era exatamente a melhorar seus aspectos físicos.

Em 2007, a professora Ângela Pôrto organizou ao abrigo da Fundação Oswaldo Cruz Doenças e escravidão: Sistema de saúde dos escravos no Brasil do século XIX. Trata-se do primeiro conjunto de estudos (primeiro grande esforço de divulgação de pesquisas) publicado sobre esse tema. São quatorze artigos dedicados a objetos diferentes (práticas de cura dos escravos, enfermidades do tráfico, amas de leite, entre outros). ${ }^{50}$ Um deles é o de Rosilene Maria Mariosa, que investigou o tratamento de escravos da Fazenda de Santo Antônio do Paiol entre 1850 e 1888. Nele sintetizou a sua dissertação concluída em 2006, na qual apresenta descobertas muito reveladoras sobre a postura senhorial em relação às condições de saúde dos cativos na mencionada fazenda.

Situada em Valença (um dos municípios cafeeiros até então mais prósperos do Vale do Paraíba Fluminense), aquela propriedade chegou a abrigar em 1879 mais de trezentos escravos. Para melhorar o tratamento da sua escravaria, seu proprietário montou uma farmácia, aproximadamente às vésperas da extinção definitiva da importação de africanos no Brasil, administrada por um farmacêutico diplomado na Escola de Farmácia de Ouro Preto, para suprir as necessidades do hospital que na fazenda havia para cuidar dos negros. A sua montagem, a contratação de profissional especializado para manipular os seus remédios, a visita periódica de médicos ao referido hospital e a internação de escravos na Santa Casa de Misericórdia local e até mesmo em clínicas particulares permitiram a autora concluir que, ao menos na propriedade por ela examinada, houve grande esforço para melhorar as condições de saúde da população cativa. E um dos indicadores de que esse esforço produziu efeitos benéficos na

49 FIGUEIREDO. In: NASCIMENTO, CARVALHO e MARQUES (2006) p. 253-254. 50 PÔRTO (2007). 
demografia escrava da propriedade é o batismo de 155 crianças entre as décadas de 1860 e $1880 . .^{51}$

Na mesma coletânea foi publicada a pesquisa de Cláudio de Paula Honorato, $O$ controle sanitário dos negros novos no mercado do Valongo. Trata-se de uma prévia do seu estudo apresentado em 2008 na dissertação intitulada Valongo: o mercado de escravos do Rio de Janeiro. Esse estudo analisa a história do maior mercado de escravos construído abaixo do Equador, as suas condições e as dos indivíduos nele comercializados, as razões de sua criação, reforma, ampliação e encerramento de suas atividades tendo em vistas as vicissitudes da escravidão e do tráfico que a abastecia. A necessidade de um estabelecimento dessa natureza revela a preocupação das autoridades públicas da cidade com a saúde de seus habitantes, uma vez que elas sabiam, em face de longos anos da experiência com tal tipo de comércio, que suas mercadorias poderiam espalhar peste (epidemia de doença mortífera altamente contagiosa). Além disso, o autor mostra que houve um esforço, com resultados modestos, mas relevantes, de vacinar os escravos recém-desembarcados contra a varíola, pois essa era uma das enfermidades pestilentas mais temidas e que mais estragos faziam na população. ${ }^{52}$ Assim, procuraram proteger os vacinados e reduzir as chances da cidade ser contaminada com tão medonha moléstia.

Ainda em 2007 foram publicados pelo menos mais dois trabalhos além dos que estão inseridos na coletânea organizada por Ângela Pôrto. À flor da terra é o título de um deles. Seu autor, Júlio César Medeiros da Silva Pereira, revela a demografia das mortes no cemitério dos pretos novos no Rio de Janeiro, especializado em enterrar escravos, sobretudo os que desembarcavam mortos ou morriam no mercado do Valongo. Sua pesquisa confirma que entre os desembarcados havia grande índice de morte, em sua maioria de homens jovens, e que uma das suas principais causas eram as gastroenterites, como observou nos atestados médicos de muitos dos que lá foram despejados. $^{53}$

Outro deles é o estudo de Ana Maria Galdini Raimundo Oda sobre banzo e outros males dos escravos na memória de Luís Antônio de Oliveira Mendes, que foi lida originalmente em 1793 na Real Academia das Ciências de Lisboa e publicada em 1812.

51 MARIOSA (2006) p. 113. Segundo a autora, farmácia contendo vários medicamentos e receitas assinadas pelos médicos que visitaram o hospital dos negros na fazenda encontra-se preservada.

52 HONORATO (2008) p. 120-122.

53 PEREIRA (2007). As confirmações acima citadas encontram-se respectivamente nas p.133 e 126. 
Uma das moléstias mais comuns na população escrava, o banzo, conhecida como doença da melancolia (sintomatizada por um profundo abatimento que normalmente culminava na morte), provocava dolorosas feridas na alma. Ao debruçar-se sobre esse assunto, a autora mostra como era percebida uma enfermidade silenciosa e como, ao abordá-la, o autor da mencionada memória identifica-se com o ideário abolicionista que então se formava a partir das críticas iluministas à escravidão.

Assim, ela apresenta um quadro muito angustiante em torno de um objeto até então bastante comentado pelos estudiosos, mas ainda sem um estudo profundo, talvez devido ao ainda quase inexistente diálogo entre a história e psicopatologia, do qual depende o aprofundamento da investigação de doenças psíquicas. Suas conclusões preliminares, seguindo os preceitos da história intelectual e tributária do já comentado estudo de Rafael de Bivar Marquese, mostram que a percepção do autor da referida memória estava pautada nas visões trágicas, que circulavam em relatos médicos e de viajantes, a qual serviu de referência para a produção de imagens e discursos antiescravistas de um abolicionismo em plena formação. ${ }^{54}$

Em meio a esse despertar historiográfico sobre o estudo das condições de saúde da população cativa, começaram a surgir trabalhos mais pontuais, além do acima abordado, com base em estudo de um texto específico que contêm informações elucidativas a esse respeito, como o de Maria Regina Cotrim Guimarães, dedicado ao estudo das doenças de escravos no Dicionário de medicina popular de Chernoviz (1842). Nele, ao procurar descrições sobre as enfermidades desses indivíduos, observando a maneira como elas são explicadas e as proposições de remediá-las, acabou descobrindo um médico crítico à situação em que se encontrava a maioria dos escravos e ao caráter clandestino do comércio de importação de africanos. Em relação a esse último ponto, sua pesquisa revela um personagem um tanto contraditório, pois, apesar da sua crítica a tal comércio, ele admitia ser o cativeiro ainda melhor do que a vida na África, reiterando o que os agentes justificadores da manutenção do tráfico africano de negros para o Brasil argumentavam. ${ }^{55}$

$\mathrm{Na}$ virada da última para a atual década o interesse dos historiadores sobre o tema em análise continua a aumentar. Entre os estudos publicados nesse período destaca-se a dissertação de Keith Valéria de Oliveira Barbosa voltada para o exame da 
mortalidade escrava no Rio de Janeiro entre 1809 e 1831 . Usando registros de óbitos e inventários das freguesias de Irajá e Candelária, a autora mostra que, devido à precariedade das condições de vida dos escravizados, seus índices de morte eram muito altos, principalmente entre as crianças, sendo as doenças dos aparelhos respiratório e digestivo, junto com as epidérmicas e parasitárias, as mais comuns entre eles.

Além de mostrar que o lugar e o período analisados também expressam em escala reduzida a situação geral do país, ela se vale de uma pesquisa na qual a autora divulga um inventário, de Bento de Oliveira Braga, feito em 1839, e outro de seu pai, com detalhadas informações sobre escravos doentes e como eram tratados. Entre elas destaca-se o arrolamento de uma casa desde fins do século XVIII para cuidar dos enfermos, o cuidado especial que se teve com um escravo tísico, mandado para uma região de clima mais propício para a sua cura e as precauções tomadas com as crianças recém-nascidas. Pode ser um exemplo extraordinário, mas como a pesquisadora parte do procedimento metodológico da micro-história praticada por Carlo Ginzbourg em seu clássico $O$ queijo e os vermes para conduzir sua pesquisa, subentende-se que ela defende a hipótese de que tal exemplo é expressão microscópica de uma realidade mais ampla. Assim, seu estudo abre uma perspectiva para trabalhos dedicados ao estudo comparativo de inventários produzidos em espaços e tempos diferentes, de forma que se for encontrado neles percentual significativo de propriedades com as mesmas ou similares informações, será possível avançar consideravelmente a historiografia sobre a saúde dos escravos no Brasil. ${ }^{56}$

Recentemente, no final de 2012, a História, Ciências, Saúde-Manguinhos publicou um suplemento, dedicado à relação saúde e Escravidão, que pode ser considerado um atestado do começo do amadurecimento da historiografia especializada nesse tema, por reunir treze artigos, decorrentes de ensaios, resultados parciais de teses e estudos avançados, que ajudam a ampliar o conhecimento da dura realidade dos escravos, ao apresentar novas informações e interpretações sobre as suas condições de saúde. Um deles foi escrito por vários pesquisadores que investigaram a mortalidade escrava durante a epidemia de cólera no Rio de Janeiro ocorrida entre 1855 e o ano seguinte. Combinando dados estatísticos do hospital e cemitérios administrados pela Santa Casa de Misericórdia com depoimentos de médicos e textos jornalísticos, os seus

56 BARBOSA (2010) p. 56. A pesquisa da qual ela retirou as informações sobre o inventário de Bento de Oliveira Braga é de SILVEIRA (1997) p. 130. 
autores mostram que a epidemia fez mais estragos na população escrava, principalmente a africana, do que na livre, devido às suas precárias condições de vida e higiene. ${ }^{57}$

Outro deles é dedicado ao tétano; uma doença que afetava em grande parte os recém-nascidos, devido à infecção no umbigo ocasionada pela falta de maiores cuidados com a assepsia durante e após o corte do cordão umbilical, aumentando ainda mais a elevada mortalidade infantil na época. Segundo o seu autor, Ian Read, essa doença, verdadeiro flagelo silencioso da demografia escrava durante séculos, declinou consideravelmente após 1850, devido ao melhor tratamento recebido, em geral, pelos escravos, pelo avanço do saber médico e pela expansão do serviço público de saúde. Isso o levou a defender que a redução dos índices de óbitos desses indivíduos nas últimas décadas da escravidão deve-se em grande parte ao maior controle da mencionada doença. ${ }^{58}$

Esse mesmo autor, também em 2012, publicou uma obra intitulada The Hierarchies of Slavery in Santos, Brazil, 1822-1888, na qual há um capítulo, Illness, recovery and death (p. 125-153), em que ele mostra que na cidade de Santos observa-se grande aumento de internação de escravos no hospital de caridade local e considerável redução da mortalidade infantil. Para ele, isso é um indicador de um cuidado maior com a saúde da população escrava, cuidado que se explica pela vertiginosa alta dos preços que o mercado de trabalhadores escravizados havia atingido após o fim do tráfico de africanos para o Brasil em 1850.

Há também mais dois estudos focados em recortes regionais, Pelotas e Belém, de cujas realidades quase nada se sabia em relação à saúde no cativeiro, que apresentam resultados muito relevantes para o progresso historiográfico desse assunto. Em relação à primeira cidade, Beatriz Ana Loner e demais pesquisadores que assinaram o artigo revelam as condições de trabalho e saúde dos escravos nas charqueadas. Em uma das atividades mais tensas (devido à maior vigilância necessária aos escravos que, para conduzirem suas tarefas, precisavam portar equipamentos cortantes para esquartejar o gado) e árduas, o trabalhador escravizado dos charques estava submetido a muitas doenças relacionadas com ambientes insalubres, como os matadouros das charqueadas, entre as quais se destacam as infecções pulmonares, parasitoses, reumatismo e moléstias

57 KODAMA et al (2012) p. 60, 62 e 65. Os gráficos entre a p. 69 e a p. 74 são usados para comprovar a maior incidência do cólera nos escravos.

58 READ (2012) p. 108-109. A tabela da p.113 e os gráficos da p. 125 e p. 127 mostram comprovam o declínio das mortes causadas por tétano no Brasil, em particular na cidade de Porto Alegre. 
do sistema digestivo, além é claro das DSTs comuns aos escravos de todas as regiões. Uma das informações mais importantes desse estudo é persistência de mau tratamento aos escravos e a insensibilidade de senhores até mesmo em casos de comoção pública. Os autores recuperaram na edição de 6 de novembro do jornal Onze de Junho o caso de Paulo, "infeliz pardo", escravo de Rodrigues Condeixa, que estava gravemente doente dos pulmões, e mesmo assim não pode se tratar devido à intransigência de seu senhor. $\mathrm{O}$ caso repercutiu, favorecido pelo contexto abolicionista então em formação, levando à intervenção do clube abolicionista local. Em represália, o proprietário deu-lhe quatorze palmatórias e ainda o obrigou a cumprir suas tarefas em seus últimos momentos de vida. No entanto, esse já não era mais o comportamento predominante na época, pois a recorrência de internações dos mesmos escravos, o aumento da quantidade de internados e a redução dos que saíam vivos do hospital indicam nova tendência, próxima das propostas ilustradas do governo dos escravos que vinham sendo publicadas desde o fim do século XVIII. ${ }^{59}$

Em relação à segunda cidade, Márcio Couto Henrique estudou o perfil dos indivíduos confinados no leprosário do Tucundubá e descobriu que quase a totalidade deles era composta de escravos abandonados pelos seus proprietários. Construído em 1815, a instituição destinava-se a confinar as pessoas afetadas pela lepra, que geralmente tinham origem nas camadas pobres da população e, por isso, ficavam à mercê da caridade pública. O fato de o maior número dos confinados serem escravizados, segundo o autor, não indica uma predisposição deles a essa então considerada medonha e intratável enfermidade, e sim porque, dada sua condição servil, eram alvos preferenciais da segregação imposta aos afetados por males altamente repugnantes. ${ }^{60}$

Além destes, há ainda alguns trabalhos em andamento, conduzidos em departamentos de pós-graduação, como o da doutoranda em história na UNESP de Franca, Ana Carolina de Carvalho Viotti, que está estudando a "atenção ao corpo escravo: dos padres da Companhia de Jesus ao doutores (séculos XVI-XVIII). ${ }^{61}$

59 LONER (2012). A história do escravo Paulo encontra-se na p. 134. Os casos de escravos reinternados várias vezes pelos seus senhores e a tabela que mostram queda aumento da quantidade de internações e diminuição de mortes dos pacientes estão na p. 149.

60 HENRIQUE (2012) p. 158.

61 Um resumo da pesquisa da referida doutoranda pode ser consultado no Caderno de resumo do III Encontro Nacional dos Pós-Graduandos em História da Ciência. UFOP, 16-18 de outubro de 2013, p. 29-30. Uma versão mais ampla do seu texto poderá ser consultada nos anais do evento, com previsão de publicação em meados de 2014 . 
Recentemente, durante o XIV Seminário Nacional de História da Ciência e da Tecnologia (Ocorrido na UFMG em outubro de 2014), vários trabalhos sobre esse foram apresentados no simpósio temático Raça, saúde e cidadania no Brasil, coordenado por Kaori Kodama e Regina Celia Lima Xavier. Entre eles o de Maria Renilda Nery Barreto; Assistência à saúde das escravas no Rio de Janeiro oitocentista, o de Imara da Silva Viana; Discursos médicos e o olhar da medicina acerca do corpo escravizado e o de Silvio Cezar de Souza Lima; Doenças e observação médica em escravos: opilação nos escritos de José Martins da Cruz Jobim. ${ }^{62}$

Neste ano, eu publiquei um livro intitulado Lágrimas de sangue no qual discuto a saúde de escravos no Brasil da época de Palmares à Abolição. Trata-se de um estudo sobre as condições de saúde da população escrava negra no Brasil. Escrito com base em farta documentação, em grande parte inédita, e amplo diálogo com a historiografia da escravidão, o livro revela como as condições de saúde dos escravos foram compreendidas por médicos, jesuítas, políticos, artistas, cientistas, fazendeiros, administradores entre outros observadores durante parte do período colonial e o todo o período imperial. O confronto dos relatos entre estes diversos observadores com documentação demográfica inédita permite elucidar como o tema foi abordado por diferentes agentes históricos ao longo do tempo e como as suas formas de abordagem exerceram influência sobre a demografia escrava em alguns empreendimentos escravistas.

Enfim, a expansão recente da quantidade e da qualidade de textos sobre as condições de vida, trabalho e saúde da população escrava ampliou tão expressivamente a produção historiográfica desse tema, que já se pode dizer que estamos próximo de consolidar um novo campo de estudos históricos, resultante da interseção da escravidão com a história da saúde, da medicina e da doença. Em outras palavras, já temos uma boa base construída para edificação de uma historiografia especializada que, ao ser fomentada por novas pesquisas, poderá dar grande contribuição para maior elucidação da experiência histórica dos indivíduos submetidos ao cativeiro, dos seus problemas de saúde e da maneira como eles foram enfrentados.

62 Caderno de programação do XIV Seminário Nacional de História da Ciência e da Tecnologia, p. 77 e 78 


\section{Referências Bibliográficas}

AMARANTINO, Márcia. As condições físicas e de saúde dos escravos fugitivos anuciados no Jornal do Comércio (RJ) em 1850. História, Ciência e SaúdeManguinhos, v.14, n 4, 2007.

ASSIS, Marcelo Ferreira de. Tráfico atlântico, impacto microbiano e mortalidade escrava. Dissertação de Mestrado em História, UERJ, 2002.

BARBOSA Keith Valéria de Oliveira. Doença e cativeiro: um estudo sobre mortalidade e sociabilidade escravas no Rio de Janeiro. Rio de Janeiro, dissertação em história, UFRRJ, 2010.

BARBOSA, Keith Valéria de Oliveira e GOMES, Flávio. Doenças, morte e escravidão africana. Ciências e Letras, nº44, 2008.

BECKER, Carolina Bitencourt. Os escravos e sua relação com a história da saúde na fronteira meridional do Rio Grande do Sul de século XIX. Anais do X Encontro Estadual de História - ANPUHRS, 2010.

BRIZOLA Jaqueline Hans. A Santa Casa de Misericórdia de Porto Alegre e o perfil de escravos enfermos no contexto do fim do tráfico negreiro no Brasil (1847-1853). Porto Alegre, dissertação em história, 2010.

CAMPBELL, John. Work, pregnancy, and infant mortality among Southern slaves. In: Journal of Interdisciplinary History, 14, p. 793-812, 1984.

CHALHOUB, Sidney et al. Artes e oficios de curar no Brasil. Campinas, Unicamp, 2003.

. Cidade febril. $2^{\mathrm{a}}$ ed., São Paulo, Cia. das Letras, 1999.

CHANDLER, David L. Health and slavary: a study of health conditions among negro slaves in the Viceroyalty of New Granada and its associated slaves trade, 1600 a 1810. Tulane, Universidade de Tulane, 1972.

COELHO, Philip R. and ROBERT A. McGuire. Diets versus diseases: the anthropometrics of slave children. In: The Journal of Economics History, v. 60, n⿳⺈ $1,2000$.

CONRAD, Robert Edgar. Tumbeiros: o tráfico de escravos para o Brasil. São Paulo: Brasiliense, 1985.

CURTIN, Philip D. The Atlantic slave trade. Madison, University of Wisconsin presss, 
Epidemioly and the slave trade. In: Political Science Quarterly, nº 83, 1968.

DAVIS, David Brion. O problema da escravidão na cultura ocidental. Rio de Janeiro, Civilização Brasileira, 2001.

BLEN, J. Ericson. Growth of the black population in Ante Bellum America, 1820-1860. In: Population Studies, no 26, p. 273-289, 1972.

. New estimates of the vital rates of the United States black population during the nineteenth century. In: Demography, no 11, p. 301-319, 1974.

EHRARD, Jean. L'esclavage devant la concience morale dês lumière française. In:Abolitions de l'esclavage. Vincennes, Presses Universitaires de Vincennes, 1995.

ELTIS, David. Nutritional trends in Africa and the Americas: heights of Africans, 18191839. In: Journal of Interdisciplinary History 12, p. 453-475, 1982.

EUGÊNIO, Alisson. Lágrimas de sangue: a saúde dos escravos no Brasil da época de Palmares à Abolição. São Paulo, Alameda, 2016.

FALCI, Miridan Britto. Doenças dos escravos .Anais do XII Encontro Regional de História-ANPUH-RJ, 2004. . e ALMEIDA, Ana Maria. Cemitérios de escravos e condições nosológicas dos escravos em Vassouras. In: Revista do Instituto Histórico e Geográfico do Rio de Janeiro. Rio de Janeiro, v. 12, nº 12, p. 211-216, 2003.

FOGEL, Robert W. and ENGERMAN, Stanley L. Time of the cross: the economics of American Negro slavery. Boston: Little, Brown, 1974.

Paulo, Unesp, 1997.

FREITAS, Octavio de. Doenças africanas no Brasil. São Paulo, Cia. Nacional, 1935.

GENOVESE, Eugene. The medical and insurance costs of slaveholding in the cotton belt. Journal Negro History, XLV, 1960.

GUIMARÃES, Maria Regina Cotrim. Os manuais de medicina popular do Império e as doenças de escravos: o exemplo de Chernoviz. Revista latino-americana de Psicopatologia Fundamental, v.11, 2008.

GUTMAN, Herbert. Slavery and the numbers game: a critique of time on the cross. Urbana, University of Illinois Press, 1975.

HENRIQUE, Márcio Couto. Escravos no purgatório: o leprosário do Tucunduba (Pará XIX). História, Ciências, Saúde-Manguinhos, v. 19, suplemento 1, 2012. 
HOLANDA, Sérgio Buarque de. Raízes do Brasil. $5^{\mathrm{a}}$ ed., São Paulo, Cia. das Letras, 1997.

Botica da natureza. In: Caminhos e fronteiras. $3^{\text {a }}$ ed., São Paulo, Cia. das Letras, 1994.

HONORATO, Cláudio de Paula. Valongo: o mercado de escravos no Rio de Janeiro, 1758-1831. Niterói, Universidade Federal Fluminense, dissertação em história, 2008.

KARASCH, Mary. A vida dos escravos no Rio de Janeiro, 1808-1850. São Paulo, Cia. das Letras, 2000.

KIPLE, Kenneth. The caribbean salavery: A biological history. Cambridge, University Press, 1984.

. The nutritional link and child mortality in Brazil. In: Hispanic, America Historical Review, v. 69, n 4, 1989.

KODAMA et al. Mortalidade escrava durante a epidemia de cólera no Rio de Janeiro (1855-1856). História, Ciências, Saúde-Manguinhos, v. 19, suplemento 1, 2012.

LIMA, Silvio Cezar de Souza. O corpo escravo como objeto de práticas médicas no Rio de Janeiro (1830-1850). Rio de Janeiro, dissertação de mestrado em história, Fiocruz, 2011.

LORNER, Beatriz Ana et al. Enfermidade e morte: os escravos na cidade de Pelotas, 1870-1880. História, Ciências, Saúde-Manguinhos, v. 19, suplemento 1, 2012.

MARIOSA, Rosilene Maria. O tratamento e doenças de escravos na Fazenda de Santo Antônio do Paiol 1850-1888. Vassouras, dissertação de história, Universidade Severiano Sombra , 2006.

MARQUESE, Rafael de Bivar. Feitores do corpo, missionários da mente: senhores, letrados e o controle dos escravos nas Américas. São Paulo, Cia. das Letras, 2004.

MELLO, Pedro Carvalho de. Estimativa da longevidade de escravos no Brasil na segunda metade do século XIX. Estudos Econômicos, v.13, nº 1, 1983.

MOREIRA, Paulo Roberto S. "Portanto, os senhores exigindo dos escravos mais do que podem, cometem homicídio": vida e morte de indivíduos cativos nos oitocentos através dos registros de óbito (Porto Alegre/RS). Espaço Plural, nº 22, 2010.

MOTA, Carlos Guilherme. Ideologia da cultura brasileira. $3^{\text {a }}$ ed., São Paulo, 
Editora 34, 2008.

NEVES, Maria de Fátima Rodrigues das. Mortalidade e morbidade entre os escravos brasileiros no século XIX. In: Anais do Encontro Nacional de Estudos Populacionais, ABEP, 1994.

PARAHYM, Orlando. Doenças dos escravos em Pernambuco. Recife, Gráfica Caxangá, 1978.

PEREIRA, Júlio César Medeiros da Silva. À flor da terra: o cemitério dos pretos novos no Rio de Janeiro. Rio de Janeiro, Garamond/IPHAN, 2007.

PHILLIPS, Ulrich B. American negro slavery. Baton Rouge, LSU, 1966.

PINTO, Natália Garcia. Trabalho e morte: um estudo das causas de falecimentos de trabalhadores cativos na cidade portuária de Rio Grande (1864-1870). Aedos, $\mathrm{n}^{\circ} 4$, v. 2, 2009.

PORTO, Ângela. Doenças e escravidão: sistema de saúde dos escravos no Brasil do século XIX. Rio de Janeiro, Fiocruz, CD-Rom, 2007.

. Sistema de saúde dos escravos no Brasil do século XIX. História, Ciência e Saúde-Manguinhos, v.13, nº 4, 2006.

. A assistência médica aos escravos no Rio de Janeiro. In: Revista Papéis Avulsos. Rio de Janeiro, Fundação Casa de Rui Barbosa, p. 13-25, 1988.

POSTEL, Willian. Dosite. The health of slaves on Southern plantations. Baton Rouge: Louisiana State University Press, 1951.

READ, Ian Um declinio triunfante? Tétano entre escravos e livres no Brasil. História, Ciências, Saúde-Manguinhos, v. 19, suplemento 1, 2012.

ROSENTHAL, Caitlin. From slavery to scientific management: capitalism and control in America (1754-1911). Mimeo, 2013.

SAVITT, Todd L. Medicine and slavery: the diseases and health care of blacks in antebellum Virgínia. Urbana, University of Illinois press, 1978.

SCHAFF, Adam. História e verdade. São Paulo, Martins Fontes, 1978.

SCHWARTZ, Marie Jenkins, Birthing a slave: motherhood and medicine in Antebellun South.

Havard, University Press, 2006.

SHERIDAM, Richard B. Doctors and slaves: a medical and demographic history of slavery in the Britsh West Indies. Cambridge, Cambridge University Press, 1985. 
SILVEIRA, Alessandra da Silva. Sacopema, Capoeiras e Nazareth: estudos sobre a formação de família escrava em engenhos do Rio de Janeiro do século XVIII. Dissertação, Campinas, 1997.

SOMARRIBA, Maria das Graças G. A medicina no escravismo colonial. Belo Horizonte, UFMG/FAFICH, textos de sociologia 1, 1984.

STECKEL, Richard H. Birth weights and infant mortality among American slaves. In: Economic History, n 23, p. 173-198, 1986.

. A peculiar population: the nutrition, health, and mortality of American slaves from childhood to maturity. Mimeo, 1985.

. Slave mortality: analysis of evidence from plantation records. In: Social Science History 3, p. 86-114, 1979.

STEIN, Stanley J. Grandeza e decadência do café no Vale do Paraíba. São Paulo,

TEIXEIRA, Heloísa Maria. Família escrava, sua estabilidade e reprodução em Mariana: 1850-1888. In: Afro-ásia, no 28, 2002.

\section{Recebido em 04/03/16 - Aprovado em 25/05/16}

